BANGLADESH JOURNAL OF SCIENTIFIC AND INDUSTRIAL RESEARCH

E-mail: bjsir07gmail.com

\title{
Physico-Chemical Parameters in Relation to Meteorological and Climatic Conditions in a Fish Pond
}

\author{
A. Nargis and S. H. Pramanik \\ BCSIR Laboratories, Rajshahi, Bangladesh
}

\begin{abstract}
Fluctuations of important physico-chemical parameters of a pond were investigated. Different pairs of variables had different relationships with each other by the relevant coefficients of correlation. The $\mathrm{pH}$ value was 7.0-7.8 and inversely related to dissolved oxygen. It is highly significant with free $\mathrm{CO}_{2}$ and $\mathrm{CO}_{3}$. Dissolved oxygen content is highly significant with water temperature, inverse relationship with free $\mathrm{CO}_{2}, \mathrm{CO}_{3}$ but no relationship with $\mathrm{HCO}_{3}$. The carbonate content was 9.8-12.5 ppm. The results showed significant influence of major components on the productivity of fishes in a pond.
\end{abstract}

Key words : Fish, Pond ecology, Dissolved oxygen, Meteorological properties.

\section{,Introduction}

The pond ecology have mostly concentrated on the physico-chemical characteristics as they are related to plankton population. The phytoplankton and zooplankton population increased as the water temperature increased (Vasisht and Sharma 1975.) Besides, plankton blooms coincided with the highest amount of light penetration, growth of silicates and alkaliniy in water (Connell and Andrews 1972). Different environmental factors which determine the characters of water have great importance to the growth, maturity, reproduction and development of fish

\footnotetext{
* Corresponding author
}

(Bhuiyan et al. 1997). Growth and abundance of zooplankton varies from month to month and also in various depth ranges depending on meteorological and water properties (Ali et al. 1989). The relationship between the fish and their biotic and abiotic environments is not an isolated phenomenon. Changes of one may reflect and affect on other. Water quality of a pond is influenced by its meteorological and soil conditions. Semi-intensive fish culture is an arrangement by which the fish receives supplemental feed in addition to the food that is naturally available in the pond. 
The objective of this study is to determine the monthly physico-chemical parameters and their evaluation relevant to proper management of fish culture in pond ecosystem.

\section{Materials and Methods}

The study was conducted over a period of twelve months between (January to December 2005) in a pond of BCSIR Laboratories, Rajshahi. It is more or less square feet (5 Bigha) with non-uniform depth, the maximum depth being about $3 \mathrm{~m}$. The pond had no inlet or outlet and was dependent on rainfall for its water.

The pond received monthly inputs in the form of compost, TSP, urea and oil cake. These inputs were supplied to increase the production of planktonic organism which constitute food for the fish. The quantities of these inputs supplied to the pond/month were urea 40, TSP 40 and oilcake $80 \mathrm{Kg}$, respectively.

\section{Water sampling collected from three areas around the pond}

Area I was located on the northern side, II located on the southern side of the pond. Area III located in between I and II.

The air and water temperature of the three areas were sampled from January 2005 to December 2005 by using centigrade thermometers. Samples were collected from the undisturbed surface of the pond at each specified area and between 9.00am and 2.00pm daily. Dissolved oxygen of the three areas was determined by the modified Azide Winkler method with drops count titration as per APHA 1976. Free carbon dioxide, carbonate and bicarbonate contents of the water were determined by a 'Field Water Analysis Kit' of HACH Company, USA.

\section{Results and Discussion}

The results of various physico-chemical parameters are presented in Table I. The air temperatures were $21.60^{\circ} \mathrm{C}$ in January and $32.40^{\circ} \mathrm{C}$ in May 2005. The water temperature was $22.70^{\circ} \mathrm{C}$ in January but $36.8^{\circ} \mathrm{C}$ in May. The air and water temperatures were closely related to each other. The correlation coefficient between air and water temperature was found to be \pm 0.68 (Table III) with a probability error of 0.10 , this relationship was found to be highly significant because the value ' $r$ ' is almost six times the value of the probability error (Shukla and Gulshan 1978). Similar results were recorded by (Zafar 1955 and Begum et al. 1989).

The direct relationship between air and water temperature was also reported by Islam et al. (1974), Miah et al. (1981) and Begum et al. (1989). The rainfall and water temperature are inversely related $(r=-0.30)$. In rainy season, surface run off and organic decomposition occur due to heavy turbidity in summer months. After monsoon, clay and soil particles settle down. So the turbidity began to increase. During spring months and specially in summer months when the air and water 
Table I. Monthly mean variation of physico-chemical parameters of the pond under study

\begin{tabular}{l|c|c|c|c|c|c|c}
\hline Months & $\begin{array}{c}\text { Air } \\
\text { temp. } \\
\left({ }^{\mathrm{O}} \mathrm{C}\right)\end{array}$ & $\begin{array}{c}\text { Water } \\
\text { temp. } \\
\left({ }^{\mathrm{O}} \mathrm{C}\right)\end{array}$ & $\begin{array}{c}\text { Dissolved } \\
\text { oxygen } \\
(\mathrm{ppm})\end{array}$ & $\begin{array}{c}\text { Free } \\
\mathrm{CO}_{2} \\
(\mathrm{ppm})\end{array}$ & $\begin{array}{c}\text { Carbonate } \\
(\mathrm{ppm})\end{array}$ & $\begin{array}{c}\text { Bicarbonate } \\
(\mathrm{ppm})\end{array}$ \\
\hline May & 29.74 & 36.8 & 13.5 & 38.5 & 7.4 & - & 66.3 \\
June & 31.00 & 33.00 & 12.0 & 27.8 & 7.3 & 11.2 & 76.2 \\
July & 29.16 & 33.40 & 16.5 & 35.2 & 7.3 & - & 59.1 \\
August & 29.94 & 35.40 & 13.6 & 32.3 & 7.4 & - & 72.1 \\
Sept. & 29.88 & 31.60 & 12.7 & 36.7 & 7.1 & 10.5 & 65.3 \\
Oct. & 26.33 & 32.10 & 11.7 & 24.8 & 7.0 & 9.8 & 63.5 \\
Nov. & 22.65 & 28.10 & 12.1 & 30.1 & 7.1 & 11.4 & 61.3 \\
Dec. & 19.75 & 27.20 & 11.8 & 45.2 & 7.5 & 12.5 & 63.5 \\
January & 17.53 & 22.70 & 10.9 & 52.3 & 7.4 & 11.7 & 65.2 \\
Feb. & 21.16 & 27.30 & 11.9 & 32.7 & 7.5 & 10.9 & 63.7 \\
March & 26.28 & 23.80 & 11.2 & 44.10 & 7.3 & 12.1 & 68.1 \\
April & 29.63 & 27.70 & 12.2 & 65.30 & 7.8 & 11.7 & 79.1 \\
\hline
\end{tabular}

temperatures are very high, then the water level decreased which is responsible for gradual increase of turbidity. Turbidity showed positive correlation with evaporation ( $\mathrm{r}=0.61)$, water temperature $(\mathrm{r}=0.56)$, rainy day $(\mathrm{r}=0.43)$, and rainfall $(\mathrm{r}=0.21)$ and negative correlation with sunshine hour ( $\mathrm{r}=-$ 0.49).

The $\mathrm{pH}$ value of the pond water was found to be 7.0 in October and 7.8 in April indicating its neutral to alkaline character. The $\mathrm{pH}$ value of water was inversely related to dissolved oxygen $(\mathrm{r}=-0.32)$ and rainfall $(\mathrm{r}=-$ 0.02). The relationship of $\mathrm{pH}$ with free $\mathrm{CO}_{2}$ and $\mathrm{CO}_{3}$ are highly significant $(\mathrm{r}=0.75$ and 0.69). Observed $\mathrm{pH}$ value around neutrality indicates that the pond quite suitable for fish culture.
Dissolved oxygen content of the pond having 16.5 ppm in July is highly significant with water temperature $(\mathrm{r}=0.65)$, inverse relationship with free $\mathrm{CO}_{2}(\mathrm{r}=-0.23)$ and $\mathrm{CO}_{2}$ ( $\mathrm{r}=-0.37$ ) but no relationship with $\mathrm{HCO}_{3}$ (Table III). Dissolved oxygen decreased suddenly after February due to high temperature. It was higher in winter but and lower in summer. Similar results were noticed by Islam and Mendres (1976), Ali et al. (1989) and Bhuiyan et al. (1997).

The amount of free carbondioxide was 24.8 ppm in October but 65.30 ppm in April. The increased free carbondioxide was possibly due to the accelerated bacterial decomposition. Highly significant relationships are also observed between free $\mathrm{CO}_{2}$ with $\mathrm{CO}_{3}$ $(\mathrm{r}=0.73)$ and $\mathrm{HCO}_{3}(\mathrm{r}=0.39)$. The free $\mathrm{CO}_{2}$ 
Table II. Weather components at Rajshahi in 2005.

\begin{tabular}{|c|c|c|c|c|c|c|c|c|}
\hline \multirow[b]{2}{*}{ Month } & \multicolumn{3}{|c|}{ Air max temperature $\left({ }^{\circ} \mathrm{C}\right)$} & \multirow[b]{2}{*}{$\begin{array}{c}\text { Rainfall } \\
\text { (mm) }\end{array}$} & \multirow{2}{*}{$\begin{array}{c}\text { No. of } \\
\text { rainy- } \\
\text { days }\end{array}$} & \multirow[b]{2}{*}{$\begin{array}{c}\text { Average } \\
\text { sunshine } \\
\text { (hour) }\end{array}$} & \multirow{2}{*}{$\begin{array}{c}\text { Evapora- } \\
\text { tion }(\mathrm{mm})\end{array}$} & \multirow{2}{*}{$\begin{array}{c}\text { Relative } \\
\text { Humidity at } \\
12 \text { noon (\%) }\end{array}$} \\
\hline & $\begin{array}{l}\text { Avg. } \\
\text { temp. } \\
\left({ }^{\mathrm{O}} \mathrm{C}\right)\end{array}$ & $\begin{array}{l}\text { Max. } \\
\text { temp. } \\
\left({ }^{\mathrm{O}} \mathrm{C}\right)\end{array}$ & $\begin{array}{l}\text { Avg. } \\
\text { min }\end{array}$ & & & & & \\
\hline $\begin{array}{l}\text { January } \\
\end{array}$ & 23.77 & 11.3 & 17.53 & 13.5 & 5 & 7.45 & 1.97 & 80 \\
\hline February & 28.17 & 15.06 & 21.61 & 101 & 3 & 8.40 & 3.76 & 70 \\
\hline March & 32.9 & 19.67 & 26.28 & 104 & 9 & 7.07 & 4.7 & 70 \\
\hline April & 35.76 & 23.6 & 29.63 & 26.8 & 4 & 8.36 & 5.9 & 72 \\
\hline May & 35.06 & 24.43 & 29.74 & 107.8 & 3 & 7.57 & 5.2 & 76 \\
\hline June & 36 & 26 & 31 & 91.4 & 11 & 7.96 & 4.96 & 77 \\
\hline July & 32.23 & 26.1 & 29.16 & 493.4 & 23 & 3.93 & 2.76 & 87 \\
\hline August & 33.13 & 26.76 & 29.94 & 161.3 & 21 & 4.10 & 3.7 & 86 \\
\hline September & 33.73 & 26.03 & 29.88 & 129.9 & 18 & 5.47 & 4.3 & 85 \\
\hline October & 29.86 & 23.2 & 26.53 & 272.0 & 10 & 5.03 & 2.96 & 87 \\
\hline November & 28.3 & 16.8 & 22.65 & - & - & 7.60 & 3.13 & 81 \\
\hline December & 26.3 & 13 & 19.75 & 0.8 & 1 & 8.23 & 2.6 & 76 \\
\hline
\end{tabular}

Table III. Correlation of co-efficients between physico-chemical parameters

\begin{tabular}{l|c|c|l}
\hline Physico-chemical pairs & Correlation co-efficient 'r' & Probability error & Comments \\
\hline Air temperature water temp. & 0.68 & 0.10 & Highly significant \\
pH dissolved $\mathrm{O}_{2}$ & -0.02 & 0.19 & Inversely related \\
$\mathrm{pH} \mathrm{Free} \mathrm{CO}_{3}$ & 0.75 & 0.08 & Highly significant \\
$\mathrm{pH} \mathrm{CO}$ & 0.69 & 0.10 & Highly significant \\
$\mathrm{pH} \mathrm{HCO}$ & 0.17 & 0.18 & Not significant \\
Dissolved $\mathrm{O}_{2}$ Free $\mathrm{CO}_{2}$ & -0.23 & - & Inversely related \\
Dissolved $\mathrm{O}_{2} \mathrm{CO}_{3}$ & -0.37 & - & Inversely related \\
Dissolved $\mathrm{O}_{2} \mathrm{HCO}_{3}$ & 0.14 & 0.19 & Not significant \\
Free $\mathrm{CO}_{2} \mathrm{CO}_{3}$ & 0.73 & 0.09 & Highly significant \\
Free $\mathrm{CO}_{2} \mathrm{HCO}_{3}$ & 0.39 & 0.16 & Significant \\
$\mathrm{CO}_{2} \mathrm{HCO}_{3}$ & 0.20 & 0.18 & Not significant \\
Dissolved $\mathrm{O}_{2}$ water temp. & 0.65 & 0.11 & Highly significant \\
Dissolved $\mathrm{O}_{2}$ Rainfall & -0.14 & - & Inversely related \\
pH Rainfall & -0.32 & - & Inversely related \\
\hline
\end{tabular}


content varied together with water temperature and rainfal (Verma 1969). $\mathrm{CO}_{2}$ level fluctuated widely while $\mathrm{pH}$ constant during the study period. The $\mathrm{pH}$ ranged from 7.0 to 7.8 indicating the alkalinity in the pond mainly due to bicarbonate.

The carbonate content was $9.8 \mathrm{ppm}$ in October but $12.5 \mathrm{ppm}$ in December. Carbonate was not observed in the water during the months of May, July and August. On the other hand, bicarbonate alkalinity was always present and it was $59.1 \mathrm{ppm}$ in July and 79.1 ppm in April. Bicarbonate showed no relationship with carbonate.

The $\mathrm{CO}_{3}$ alkalinity showed positive relationship with rainfall $(\mathrm{r}=0.31)$ and evaporation $(\mathrm{r}=0.11)$. The bicarbonate showed inverse relationship with rainfall $(\mathrm{r}=-50)$ and evaporation $(\mathrm{r}=-0.11)$. The $\mathrm{HCO}_{3}$ alkalinity above $40 \mathrm{mg} / 1$ is considered to be hard water (Moyle 1947 and Mathew 1975) which help to maintain the $\mathrm{pH}$ value in alkaline condition.

\section{Conclusion}

From the above observation it is evident that the productivity of the pond is medium to high. So, it may be concluded that physicochemical changes which occurred in the pond will not affect fish culture considerably.

\section{References}

Ali, S. Chowdhury, A.N. Chowdhury, D.R. Begum, S. (1989) Studies on seasonal vari- ations of physico-chemical and biological conditions in a pond. Dhaka Univ. study Pt. E. 4(2): 113-123

APHA. (1976) Standard methods for the examination of water and waste water (14th ed.). American Public Health Association, Washington, 1193pp.

Begum, A. Mustafa, G. Ali, S. Ahmed, Kh. (1989) Studies on limnology in minipond and growth of Tilapia (=Ricochromis nilotica). Bangladesh J. Zool. 17(1): 35-45

Bhuiyan, A.S. Nahar, Q. Islam, N. (1997) Physico-chemical condition in relation to meteorological condition of a fish pond in Rajshahi. Univ. J. Zool. Rajshahi Univ. 16: 85-88

Connell, M.F.O Andrews, C.W. (1972) Plankton Ecology in Long Pond, St. Johns Newfoundland: A polluted pond characterized by a high flushing rate. Int. Revue Ges. 62: 133-152

Islam, A.K.M.N. Mendes, F. (1976) Limnological Studies of a Jheel in Sher-e-Bangla Nagar. Dacca Univ. Study Pt. B. 24(2): 6371

Islam, A.K.M.N. Haroon, A.K.Y. Zaman, K.M. (1974) Limnological studies of the river Buriganga. Dacca Univ. Stud. Pt. B. 22 (2): 99-111

Mathew. P.M. (1975) Limnology productivity of Govindgeth lake, Rewa, Madhya Pradesh. 


\section{J. Indian Fish Soc. 7: 16-24}

Miah, M.I. Bhuiyan, N.I. Dewan, S. (1981) A comparative study of the rate of growth of major carps in relation to physico-chemical and biological factors. Proc. 3rd Nat. Zool. Conf. 215: 223

Moyle, J.B. (1947) Some indices of lake productivity. Trans Amer. Fish Soc. 76: 322-324

Shukla, M.C. Gulshan, S.S. (1978) Statistics: Theory and Practice. S. Chand and Company Ltd. New Delhi, 863.

Vasisht, H.S. Sharma, B.K. (1975) Ecology of a typical urban pond in Ambala city of the Haryana State. Indian J. Ecol. 2: 79-86
Verma. N.M. (1969) Hydrobiological study of a tropical impoundment, tekanpur reservoir, Goalior, India with special reference to the breeding of Indian carps. Hydrobiol. 34: 358-368

Zafar, A.R. (1955)On the periodicity and distribution of algae in certain fish ponds in the vicinity of Hyderabad, India. Doctoral dissertation at Osmania University, India.

Received :February, 10, 2008;

Accepted : April, 21, 2008. 